\title{
2 Shīin and Other Figures of the Misogamist Woman in Persian Literature
}

Summary 1 Shīrīn, the Lady of the Castle. - 2 Shīrīn's Aunt Mihīn Bānū. - 3 Shīrīn and the Misogamist Handmaiden. - 4 Shīrin and the Interdiction Against Sexual Intercourse Due to a Prediction.

\section{Shirin, the Lady of the Castle}

One of the components in the formation of the Turandot character can be traced back to the development of the literary figure of Shìrin. A number of studies have shown that the character of Shīinn, the heroine of Nizāmī's poem Khusraw va Shïin (composed between 571/1176 and 576/1181, with later additions), has a historical origin: she was the famous Christian wife of Khusraw II Parviz (r. 580-628 CE). ${ }^{22}$ Beyond historical traits, a number of legendary features were soon added to historical Shirin to create her literary figure. ${ }^{23}$ One of them is the superimposition of her character on that of the legendary queen Semiramis, a queen as strong and wise as a man, whose historical kernel can be traced back to Sammuramat, an Assyrian queen (r. 809-806 BCE ca) bearing, on an inscription repeated on several statues of Nebo, the title of 'Lady of the Palace'. ${ }^{24}$

22 See above, part I, ch. 1, § 2 fn. 3.

23 The most complete survey of the sources on Shīin's legendary figure is still that given by Aliev, Legenda o Khosrove i Širin, 21-36 (Byzantine, Armenian, and Syriac sources) and 36-57 (Muslim sources).

24 Eilers, "Semiramis". On Sammuramat and the historical data referring to this queen see in particular 33-46. On the legend of Semiramis see more recently Bernbeck, "Sex/Gender/Power and Šammuramat", with interesting methodological remarks on the relationship between history and legend. 
Sammuramat is connected with the regions of western Iran and Armenia, as is Nizāmī's heroine. In Nizāmī's poem, Shīrīn spends a relevant part of the narrative time alone, closed in her castle, the famous Qașr-i Shirin, a castle that Khusraw's handmaidens had arranged to be built in a noxious place, out of envy for her beauty. ${ }^{25}$ She is a bānū-yi hișārī (Lady of the Castle) like Sammuramat, and like the princess in the Tuesday tale in Nizāmi's Haft paykar. ${ }^{26}$ That of being a 'Lady of the Palace/Castle' may have been one of the literary motifs connecting Sammuramat, through Shīinn, to the anonymous princess in Nizāmī's Tuesday tale.

\section{Shīrīn's Aunt Mihīn Bānū}

Beyond the Lady of the Castle motif, in the literary development of Shīin's character other features are relevant in order to bring to light early stages of the character of Turandot. Some of them also pertain to Shīrīn's aunt Mihīn Bānū (The Grand Lady), ${ }^{27}$ whose proper name according to Nizāmī (Shamīrā, rather than the Arabized form Shumayrā ${ }^{28}$ ), in itself connects her with the legendary queen Semiramis. ${ }^{29}$ Mihīn Bānū's location in Barda', where she winters, ${ }^{30}$ is particularly meaningful: in the first part of his Romance of Alexander, the Sharaf-nāma (Book of Honor ${ }^{31}$ ), Nizāàī places another female character in Barda': queen Nūshāba.

As is well known, in the Nūshāba episode Nizāmī reworks a particular episode of the Greek Pseudo-Callisthenes Alexander romance: Alexander's visit, in disguise, to queen Kandake. ${ }^{32}$ But when Niẓāmī

25 Nizāmī, Khusraw va Shīrīn, ch. 26, 9-39. The ruins of Shīrīn's Castle (Qașr-i Shīrīn) are traditionally identified in the remains of Sasanid palaces near the city of this name in Jibal or Persian Iraq; see Streck, s.v. "Kasr-i Shīrīn"; and Le Strange, The Lands of the Eastern Caliphate, 63.

26 In Persian the princess of Nizāmī's Tuesday tale is usually referred to as bānū-yi hișārī. See Bürgel, "Turandot - Von Nizāmī bis Puccini", 350 fn. 3. In Persian this expression also implies a meaning of confinement or (self-)imprisonment.

27 On Mihīn Bānū, see Nizāāī, Khusraw va Shīrīn, ch. 17, 13-29. On this character and its origins cf. Orsatti, "Le donne e le città", 140-4.

28 Niẓāmī, Khusraw va Shīrīn, ch. 17, 20.

29 Eilers, "Semiramis," 56-8 and fn. 100. Already in the Pseudo-Callisthenes Romance (Book III, 18), Kandakes's kingdom was identified with that of Semiramis.

30 Niẓāmī, Khusraw va Shīrīn, ch. 17, 26.

31 On the complex question of the date of the first part of Nizāmī's Iskandar-nāma see de Blois, Persian Literature, V, pt. 2, 442-6; and V, pt. 3, Appendix II: Some Afterthoughts on the Chronology of Nizāmī's Works and that of the Sharwān-shāhs, 585-91.

32 On the figure of Kandake (Qaydāfa/Nūshāba) in Persian sources, see Rubanovich, s.v. "Qaydāfa"; and "Re-Writing the Episode of Alexander and Candace in Medieval Persian Literature", 123-52. 
states that the ancient name for Barda' was Harūm, ${ }^{33}$ this location offers another key to the comprehension of the Nūshāba and - moreover - of the Mihīn Bānū character: indeed, in the Shāhnāma, in the episode of Alexander's visit to the Amazons, these famous women warriors are located in Harūm or thereabouts; and, in some lexica, Harūm is defined as 'The city of women'. ${ }^{34}$

In Nizāmī's Sharaf-nāma Nūshāba is described as the queen of a realm of women; she is surrounded, served and advised by women alone, and no man is allowed to approach her, not even - as was usual in Niẓāmì's own world - her relatives. Her male subjects live, separately, in another region, and never dare to approach, despite offering their military services when need arises. ${ }^{35}$ Therefore it is clear that, in the Sharaf-nāma, the episode of Nūshāba represents the point of convergence of two different episodes of the Pseudo-Callisthenes Alexander romance, which are still separate in the Shāhnāma: that of Alexander's visit to Kandake/Qaydāfa, ${ }^{36}$ and that of the Amazons. ${ }^{37}$

In the poem Khusraw va Shīrin, Mihīn Bānū, whom Niẓāmī places - like Nūshāba/Kandake - in Barda', is likewise depicted as the queen of a realm of women alone. Arrān, in eastern Transcaucasia, and Armenia, the regions where she lives, are not too far from the country where the Amazons lived according to Greek tradition: the banks of the river Thermodon and the south-west shores of the Black Sea. (According to the Muslim tradition, instead, the fabulous country of these warrior women was much more to the west and to the north, being variously identified with Egypt, Yemen, or with a country not far from the north pole ${ }^{38}$ ). It would not be impossible, therefore, to see the literary character of Mihīn Bānū as embodying the legendary figure of the queen of the Amazons. ${ }^{39}$ This would explain the anomaly whereby

33 Nizāàì, Sharaf-nāma, ch. 36, 19.

34 Dihkhudā, Lughat-nāma, s.v. "Harūm", gives the following definition, in a quote from the Burhān-i qātic: "The name of the city of women. Some commentators maintain this to be the present-day Barda'”.

35 Niẓāmī Ganja'ì, Sharaf-nāma, ch. 36, 26-33. For an account of a similar gender division in Islamic literatures, cf. Arioli, Le isole mirabili, 191-2.

36 Pseudo-Callisthenes, Historia Alexandri Magni, 115-23 (III: 18-23); Firdawsī, Shāhnāma, 6: 51-74 (Iskandar, 1l. 671-1055).

37 Pseudo-Callisthenes, Historia Alexandri Magni, 124-9 (III: 25-7); Firdawsī, Shāhnāma, 6: 85-90 (Iskandar, ll. 1233-327).

38 On the Amazons, cf. Shapur Shahbazi, s.v. "Amazons". On the location of the country of the Amazons in Muslim sources and on the etymology of the name Harūm, cf. Monchi-Zadeh, Topographisch-historische Studien zum iranischen Nationalepos, 172-6.

39 Orsatti, "Le donne e le città", 140-1. A link between some feminine characters in Nizāmì's poem and the myth of the Amazons has been suggested by several other scholars. See, among others, Tughiyānī, Mu'īnī Fard, "Ārmān-shahr-i zanān dar Khusraw va Shīrīn-i Hakīm Nizāmī-i Ganja'ī”; and Karamī, "Bar-rasī va tahlīil-i 'shāh-zan' dar nigāh-i Niẓāmī”. 
only Shìrin's aunt appears in the poems, but never her parents, who would have no place in a city of women. This can also explain the development that the character of Mihīn Bānū underwent after Nizāmī. Hātifī, in his poem Shīrin va Khusraw (written between 889/1484 and 895/1490), takes the figure of Mihīn Bānū to its extreme. She is described as a masculine woman: wise, fearless, childless, she has a male countenance and no need of men; she is compared to a lion (not a lioness); she is an excellent swords(wo)man, and in battle is able to outstare a lion. ${ }^{40}$ The only thing she fears is love; when she becomes aware of the exchange of amorous glances and gestures between Khusraw and her niece, "just thinking - Hātifī says - of a union between sugar and milk, her heart was transfixed as by a dagger or an arrow".41

Through her literary kinship with the Amazons, Shīrin may have inherited the feature of the woman who escapes from sexual intercourse, one of the features of the character of Turandot. Her strenuous resistance to Khusraw's advances, in Nizāmī's poem and even more so in some later responses to Nizāmīs poem such as that by Amīr Khusraw Dihlavī (d. 725/1325), coupled with some stubbornness in her character, ${ }^{42}$ and with the tradition of her infertility (see below), may originate from this literary background.

\section{Shīrin and the Misogamist Handmaiden}

Some elements of the figure of Shīrin and her aunt Mihīn Bānū can also be recognized in the heroine of another tale from Nizāmī's Haft paykar, the Sunday tale recounted by the daughter of the Qayșar of Rüm. ${ }^{43}$ Two features link this tale with the narrative in the Tuesday tale: the heroine, a beautiful handmaiden, flees from relations with men as does - at least initially - the princess in the Tuesday tale; and, secondly, both the hero - a pleasure-seeking prince who falls in love with the handmaiden - and the handmaiden must answer personal questions (not true riddles, however), in order to achieve union. ${ }^{44}$

The tale is as follows. A prince, who passes from one woman to another being unable to fall in love with any of them, at last falls in love

40 Hātifī, Shīrīn va Khusraw, 31, ll. 401-6.

41 Hātifī, Shīrīn va Khusraw, 59, l. 777.

42 Cf. Orsatti, "Le poème Xosrow va Širin de Nezāmi et ses répliques par Amir Xosrow et Jamāli”, 167-71.

43 Niẓāmī, Haft paykar, ch. 33.

44 The motif of the personal questions within the couple also recurs in a short anecdote about Bilqīs and Solomon inserted into the same Sunday tale (for a summary, see the following note). Riddles revolving around personal, often incestuous, tabooed or socially sanctioned matters are frequent in literature. Suffice it to recall the Apollonius of Tyre romance, on which see Goldberg, Turandot's Sisters, 20. 
with the only woman who resists him, a beautiful handmaiden who, however, flees from physical relations. The prince asks her to be sincere with him and explain the reasons for her conduct; a procedure which - he says - has often proved successful in overcoming a difficulty (here, as illustration, a curious tale is inserted into the main story, concerning queen Bilqīs and Solomon ${ }^{45}$ ). The handmaiden, in her turn, asks the reason why the prince passes from one woman to another. The prince answers that he has found no sincere and honest woman until then, and now that he has found her, he only wants her love. The handmaiden, in her turn, confesses that she flees from men because her horoscope has warned that the love of a man would put her life at great risk. However, this confession does not have the expected effect. At this point an old woman intervenes: just as custom has it in horse-breaking, she counsels the prince to 'saddle' already tamed 'fillies' in the girl's presence. Stung by jealousy, the girl suffers deeply to the extent of almost dying, just as her horoscope had foreseen; the shrew is tamed and love is crowned with union.

In this tale it would be tempting to see, behind the figure of the handmaiden, a reflex of the literary character of Shïrin: indeed, according to some sources, Shīin was only one of Khusraw's handmaidens; ${ }^{46}$ and the way she is depicted in the Shähnāma leaves no doubts as to her humble origins (at least according to some traditions, possibly of Sasanid origins). ${ }^{47}$ Shīrin's strenuous resistance of Khusraw's advances in Nizāamì's and other poems may find a parallel in the character of the misogamist handmaiden of the Sunday tale. A final element of the plot is relevant in order to connect the handmaiden of the Sunday tale with the character of Shinin: the motif of sexual intercourse forbidden by a prediction is to be found in a tradition concerning Shīrīn reported by Tabarī.

45 The anecdote is as follows: a baby is born to Bilqīs and Solomon, which has neither arms nor legs. As the only possible cure the archangel Gabriel suggests that, during intimacy, the two be sincere and answer honestly the questions they pose each other. Solomon asks Bilqīs if she has ever desired other men, apart from him; Bilqīs asks if he has ever coveted another's goods. When they respond honestly, their son gains his arms and legs (Nizāmī, Haft paykar, ch. 33, 95-132). For a study of the sources and development of the tale of Bilqīs and Solomon, cf. Wesselski, "Quellen und Nachwirkungen der Haft Paikar", 116-19.

46 Bal'amī, Tārīkh, 2: 1091-2; Mujmal al-tavārīkh va'l-qiṣaș, ed. Bahār, 79.

47 Cf. Firdawsī, Shahname, 8: 259-70 (Khusraw Parvīz: Dāstān-i Khusraw bā Shīrīn, 11. 3387-515). On the figure of Shīinn in the Shahname see Khaleghi Motlagh, Die Frauen im Schahname, 84-8 (= 67-71 of the enlarged English edition); and van Ruymbeke, "Firdausi's Dastan-i Khusrau va Shīrinn: Not much of a Love Story!", 125-47. 


\section{Shīin and the Interdiction Against Sexual Intercourse Due to a Prediction}

The motif of the ban on sexual intercourse due to a prediction or a horoscope is to be found in a short narrative concerning Shīin recounted by Ṭabarī (d. 310/923), in his Ta'rīkh al-rusul wa'l-mulūk, and - with slight differences - in the Persian adaptation of the latter by Bal'amī (begun in 352/963). Shīrin appears here in her traditionally negative aspect ${ }^{48}$ as an infertile woman - a datum probably pertaining to the historical Shīrīn ${ }^{49}$ - and, worse still, as indirectly responsible for the fall of the Sasanid empire. Indeed, in this tale the foretold danger is the birth of a child under whose reign the power of Persia would come to an end. The source of the story is Hishām b. Muhammad, who can certainly be identified with the famous scholar Ibn al-Kalbī (d. 204/819 or 206/821). ${ }^{50}$

According to this tradition, Khusraw had been warned by the court astrologers that one of his sons would have a son with a physical defect, under whose reign the kingdom of Persia would be destroyed. For that reason he gives orders to keep his sons separate from all women. Shīinn had adopted Shahriyār, the eldest of Khusraw's eighteen sons (according to this tradition, therefore, Shīinn was permanently infertile). ${ }^{51}$ As Shahriyār complains about his lust for women, Shīin at last provides him with one of her maids, a hideous woman she thinks will be of no use to him. Instead, Shahriyār immediately leaps on her, and she becomes pregnant with Yazdagerd (Yazdagerd III), the last Sasanid king. ${ }^{52}$

In this story the ban on sexual intercourse does not affect Shīrīn (the handmaiden in Nizāmī's tale), but Shīrīn's putative son Shahriyār. However, as will appear from a late reworking of this anecdote placed in a different historical context, through the motif of the interdiction against sexual intercourse dictated by reasons of state the character of Shìrin appears relevant to the development of that of Bürāndukht (see below, ch. 5, § 3).

48 On the negative traits of Shīrīn's character, even emerging from Nizāmī's poem see Orsatti, "Le donne e le città", 146-8.

49 Her initial infertility is attested by Theophylact Simocatta, a seventh-century Byzantine historian, who quotes the text of a probably authentic letter written by Khusraw concerning Shīin; see The History of Theophylact Simocatta, 151 (V: 14). On this letter, see Orsatti, s.v. "Kosrow o Širin and its Imitations".

50 See Atallah, s.v. "al-Kalbī: II. Hishām b. Muhammad b. al-Sā’ib al-Kalbī”.

51 Shahriyār, instead, is given in the Shāhnāma as one of the four sons Khusraw had had by Shīrīn. Cf. Firdawsī, Shāhnāma, 8: 368 (Shīrūya, ll. 551-2).

52 Tabarī, History, V: The Sāsānids, 379-80. This anecdote is told with slight differences by Bal'amī, Tārikh, 2: 1147-50. On this tale, see Sprengling, "From Persian to Arabic", 219-20 